\title{
Economics of Information Technology and the Media
}


This page is intentionally left blank 


\title{
Economics of Information Technology and the Media
}

\author{
Linda Low \\ Department of Business Policy \\ National University of Singapore
}

World Scientific

Singapore $\cdot$ New Jersey $•$ London $•$ Hong Kong

a. 8

IC: SINGAPORE UNIVERSITY PRESS

NATIONAL UNIVERSITY OF SINGAPORE 


\section{Published by}

Singapore University Press

Yusof Ishak House, National University of Singapore

31 Lower Kent Ridge Road, Singapore 119078

and

World Scientific Publishing Co. Pte. Ltd.

P O Box 128, Farrer Road, Singapore 912805

USA office: Suite 1B, 1060 Main Street, River Edge, NJ 07661

UK office: 57 Shelton Street, Covent Garden, London WC2H 9HE

\section{British Library Cataloguing-in-Publication Data}

A catalogue record for this book is available from the British Library.

\section{ECONOMICS OF INFORMATION TECHNOLOGY AND THE MEDIA}

Copyright $\Theta 2000$ by Singapore University Press and World Scientific Publishing Co. Pte. Ltd.

All rights reserved. This book, or parts thereof, may not be reproduced in any form or by any means, electronic or mechanical, including photocopying, recording or any information storage and retrieval system now known or to be invented, without written permission from the Publisher.

For photocopying of material in this volume, please pay a copying fee through the Copyright Clearance Center, Inc., 222 Rosewood Drive, Danvers, MA 01923, USA. In this case permission to photocopy is not required from the publisher.

ISBN 981-02-3843-6

ISBN 981-02-3844-4 (pbk)

Printed in Singapore. 
To Wai Seng, Susan, Vincent and Peggy 
This page is intentionally left blank 


\section{Foreword}

As we prepare to welcome the dawn of the new century, we feel increasingly overwhelmed by the development and application of new information and communications technology (ICT). The new media and new information technology (IT), in their ever-changing forms, are shaping every aspect of our lives from work to education to leisure to the management of interpersonal relations, from the office to the family to the school, and from politics to entertainment to culture to the economy. All indications suggest that we will see more new media and IT, in their hybrid and convergent forms, being developed and introduced as we enter the new millennium.

Sociologists tell us we are living in an information society, while economists stress the growth of the information sector of the economy. Communication researchers, on the other hand, focus on the changing process of communication, the new network of distributing and disseminating information and the social and political impact of the new ICT. What is missing is an analysis of information, information technology and the new media, as well as their content as economic goods. An analysis of the process of production, distribution and consumption of such goods requires a new perspective grounded in classic economics. Similarly, the laws of supply and demand can be applied, but only with some qualifications. Our understanding of modern communication would be incomplete without an informed analysis of the economic dimensions in this era of new ICT.

This book fills the gap. It applies an economics framework to an analysis of the nature and scope of information technology and the new media. It is a welcome addition to the scholarly literature in both economics and communication studies. 
For the author, this book complements her earlier works on Professionals at the Crossroads (Times Academic Press, 1996), Housing a Healthy, Educated Wealthy Nation through the CPF (Times Academic Press, 1997) and Political Economy of City-State: Government-made Singapore (Oxford University Press, 1998). It introduces a new perspective for all students and researchers of new information technology and the media.

Eddie C. Y. Kuo School of Communication Studies Nanyang Technological University

Singapore 


\section{Preface}

Information exploding through information technology and the media has become a central, rather than peripheral, resource in the knowledge-based production of goods and services involving suppliers, producers, information providers and information users. An economic framework using supply and demand to attain equilibrium to denote the efficient allocation of the factors of production and optimum welfare is appropriate in considering the economics of information technology and the media.

Information technology and the media is undergoing rapid change and development and defining the nature and scope of this area is not an easy task. Neither is it simple to analyse the field from an economics perspective since socio-political and legal dimensions are also involved. The impact of the information and communications technology (ICT) revolution is both shrinking and expanding the global economy and creating many paradoxes (Naisbitt, 1994), even as it breaks the tyranny of space and time or causes the death of distance (Caincross, 1997). This book tries to meet the challenge in four parts.

Part I addresses the economics of information. Chapter 1 introduces various concepts and definitions of information, information technology, knowledge and information economy and media. Chapters 2 and 3 cover relevant theories and principles in both macroeconomics and microeconomics.

Part Il focuses on the players and markets in information technology and the media, namely, sellers and buyers (chapter 4) and the government (chapter 5). The impact on employment and labour (chapter 6), the role of technology (chapter 7) and the management of information, especially with multimedia (chapter 8) further highlight the relationships and interactions between players and markets. 
Part III considers public policy in the national context (chapter 9) and the global sphere (chapter 10). Both national information infrastructure and global information infrastructure have spawned information and media networks in order to operate efficiently and effectively. Increasing and liberalising trade in telecommunications services allow more countries to enjoy the socio-political and economic benefits of a global economy connected in a fluid, seamless form. Finally, Part IV presents empirical evidence, applications and case studies from the Asia-Pacific region.

The book is motivated by a general lack of educational material on the economics of information technology and media. Yet, in many countries in the Asia-Pacific, mass communications and the media are growing in importance as subjects are taught at both the university and polytechnic levels within communications, management or engineering departments. The book can be used as a textbook, a source book or a structured synthesis for teaching, research or policy making on the subject. It will complement the extant literature on other technical aspects and project the contribution of economics and other social sciences on information technology and the media.

Linda Low 


\section{Contents}

Foreword vii

Preface $\quad$ ix

Part I The Economics of Information

Chapter 1 Overview of Information Technology and the Media 3

Introduction 3

A Revolution in Information and Communications

Technology 3

An overview of new technologies 4

The sequence of the information technology revolution 5

Convergence $\quad 8$

Industry value chain $\quad 10$

Definitions and concepts $\quad 12$

Knowledge economy $\quad 15$

Information economy $\quad 16$

Information society $\quad 18$

The Nature and Scope of Information Technology and the Media $\quad 21$

The Measurement of Information and Services 22

Conceptualising the information sector 22

Input-output tables 24

Chapter 2 Basic Economic Principles and Concepts 29

Introduction 29

The Laws of Demand and Supply 31

Elasticity Measures $\quad 34$ 
Indifference Curves $\quad 35$

Budget Lines $\quad 37$

Price Effects $\quad 38$

Cost, Revenue and Profit 39

Scale and Economies $\quad 41$

Eccnomies of Scope $\quad 43$

Productivity 43

Public Goods and Externalities $\quad 44$

Chapter 3 Market Structure and Competition 46

Introduction $\quad 46$

Market Structure $\quad 46$

Consumer surplus and deadweight loss $\quad 47$

Perfect Competition $\quad 49$

Monopolistic Competition 51

Oligopoly $\quad 52$

Monopoly 54

Regulating a monopoly $\quad 57$

Price discrimination $\quad 59$

Natural monopolies in telecommunications $\quad 60$

Public Policy and Competition $\quad 61$

Who's Who in Competition 64

Information technology $\quad 64$

Hardware $\quad 64$

Software $\quad 66$

Services $\quad 66$

Part II Players and Markets in Information Technology and the Media

Chapter 4 Information Technology and Media Markets 71

Introduction $\quad 71$

Terminology and Etymology of the Mass Media 71

The role of the mass media $\quad 73$

The Telecommunications Industry $\quad 74$

Origins $\quad 74$

The Computer Industry $\quad 79$

Origins $\quad 79$

Computer hardware $\quad 80$

The economics of computer software 81

The Broadcast Industry $\quad 85$ 
Transmission and delivery modes $\quad 85$

Payment and revenue modes $\quad 87$

Broadcast Television $\quad 87$

Origins $\quad 87$

Organisation $\quad 89$

Programme production and the sale of broadcast rights $\quad 89$

Programme packaging $\quad 91$

Television networks $\quad 91$

The delivery of programmes $\quad 93$

Cable and Satellite Television $\quad 94$

Origins 94

Distribution, convergence and competition $\quad 94$

Radio $\quad 96$

Recording and Motion Pictures 97

Recording $\quad 97$

Motion picture $\quad 97$

Newspapers $\quad 98$

Chapter 5 Government Intervention and Regulation 101

Introduction 101

The Theory of a Public Good 101

The Principal-Agent Theory 102

Approaches to Intervention $\quad 104$

State-Owned Enterprises $\quad 105$

Information as a Public Good 107

The Role of Government in Information and the Media $\quad 109$

Civil society 109

Broadcast and cable television $\quad 112$

Telecommunications $\quad 113$

Newspapers 114

Chapter 6 Information Technology, Labour and Employment 116

Introduction $\quad 116$

New Economics $\quad 116$

New capitalism $\quad 116$

$\begin{array}{ll}\text { Globalisation } & 117\end{array}$

Knowledge economy 119

Technological and employment trends $\quad 120$

The Economic Impact on Work $\quad 123$

Rethinking work 125 
The effect on productivity $\quad 128$

$\begin{array}{lr}\text { Outsourcing } & 129\end{array}$

Contingent labour $\quad 130$

Part-time employment 131

Job sharing 133

Displaced and discouraged workers $\quad 133$

Downsizing 134

Sufficiency of jobs 138

Social contract and class distinctions $\quad 140$

Unionisation $\quad 142$

Spatial issues $\quad 143$

Gender issues $\quad 144$

Impact on older persons $\quad 146$

Other social issues $\quad 147$

Human Resource Development 148

Chapter 7 Technology and the Market 151

Introduction 151

Technological Trends and Developments 153

Technology in the electronics industry 157

Artificial intelligence $\quad 162$

Virtual reality 162

Technological Convergence $\quad 163$

Synergy, convergence and multimedia $\quad 165$

The Architecture of Computer Technology 166

The Economics of Networks and Social Capital 168

ISDN 171

Internet $\quad 172$

Electronic commerce $\quad 176$

The globalisation of technology 179

Chapter 8 Information Management 181

Introduction 181

The Nature of Information Management 181

Concepts and definitions $\quad 181$

Managing change 183

Change and progress 184

Reengineering 185

Definition $\quad 185$

Reengineering and work $\quad 185$ 
Reengineering and unions $\quad 188$

A business diamond $\quad 188$

Porter's diamond $\quad 189$

Business Process Reengineering 190

Learning Organisations 191

Systems thinking 192

Personal mastery 193

Mental models $\quad 193$

Shared vision $\quad 194$

Team learning 194

Tools for Information Management 194

Information audits 195

Benchmarking $\quad 195$

Other tools 196

Part III Public Policy and the Global Economy

Chapter 9 National Information Policy 199

Introduction 199

A Framework for a National Information Policy 199

National Information Infrastructure 201

Broadband capacity 203

Data compression 203

Network intelligence and flexibility 204

Networked computer servers $\quad 204$

Interactive capabilities $\quad 204$

Multimedia services and applications 204

Intelligent information applications $\quad 205$

Navigational tools 205

Problems and Issues 205

Gatekeeper 205

The role of the government 206

Digital paradox 206

Abundance, not scarcity $\quad 207$

Policy implications $\quad 207$

US policy 208

Chapter 10 Information Technology and the Media in the

Global Economy 210

Introduction $\quad 210$

Global Information Infrastructure 211 
International Trade in Services 213

The relationship between trade and infrastructure $\quad 213$

The General Agreement on Trade in Services 215

Issues in trade in services $\quad 216$

Global Trade in Telecommunications $\quad 217$

WTO Basic Telecommunications Agreement 218

WTO Information Technology Agreement 219

Trade-related intellectual property 221

Chapter 11 Issues in Media and Information Economics 223

Introduction $\quad 223$

Equity $\quad 223$

Haves and have-nots 223

Universal access $\quad 225$

Falling costs $\quad 226$

Developed versus developing world 227

$\begin{array}{ll}\text { Privacy } & 228\end{array}$

Perverse privacy 230

The Legal and Regulatory Environment 230

The role of the government 230

Cyberlaw 231

Screening 233

Intellectual property rights and piracy 233

Piracy rates $\quad 235$

Competition $\quad 237$

Socio-Political Issues $\quad 237$

The clash of civilisations $\quad 237$

Culture industries 238

The civil society and democracy 239

The global village and politics $\quad 239$

American pop culture $\quad 240$

Social base 241

Government and the nation-state 242

Part IV Information Technology in the Asia-Pacific

Chapter 12 Trends and Applications in the Asia-Pacific 247

$\begin{array}{ll}\text { Introduction } & 247\end{array}$

Geographic Shifts in the Electronics Industry 249

Factors for the global shift 250

Distinctive features of the semiconductor industry in Asia 251 
The national electronics industry

The United States

Japan

Western Europe

South Korea

Taiwan

Singapore, Malaysia and Thailand

Hong Kong and China

Latin America

International economic competition in electronics

Trade conflicts

Singapore's National Information Infrastructure $\quad 270$

Broadcasting

Telecommunications

272

Cable television

273

Satellite broadcasting

274

The national information infrastructure $\quad 274$

Malaysia's National Information Infrastructure 278

The Multimedia Supercorridor

278

Telecommunications and broadcasting

278

Hong Kong's National Information Infrastructure

280

Telecommunications and broadcasting

280

Comparative Analysis and Issues in the Rest of Asia

Democracy

Censorship

Privacy

Intellectual property rights

Equity

Culture

An Asian dilemma: the case of Singapore

Conclusion and Policy Implications

Lessons from developed countries

Policy implications

Glossary of Terms in Information Technology and the Media 